\title{
ARTICLES
}

Submitted 08.25.2012. Approved 03.13.2013

Evaluated by double blind review. Scientific Editor: Alexandre de Padua Carrieri

DOI: http://dx.doi.org/10.1590/So034-759020140402

\section{WHAT IS THE USE OF A SINGLE-CASE STUDY IN MANAGEMENT RESEARCH?}

\author{
Para que serve um estudo de caso único na pesquisa de gestão? \\ ¿Para qué sierve un estudio de caso único en la investigación de gestión?
}

\begin{abstract}
The purpose of this article is to present a defense of the use of single case studies in management research. The defense is necessary because this type of research has been relegated to a secondary role, or even rejected, by many researchers, who consider it unscientific. Evidence of this low status is the fact that most reputable academic journals in management publish few articles based on single-case studies. In this paper, we examine in detail the objections to the use of such cases in management research. We show the efforts made by some researchers to answer these objections and we show quality criteria for research that are alternatives to the criteria used in the so-called "scientific method." Our analysis suggests that a better understanding - by researchers with different methodological preferences - of the arguments for each particular use of the single-case study as a research method would allow a better dialogue between researchers and benefit management research as a whole.
\end{abstract}

KEYWORDS | Management research, single-case study, research methodology, scientific method, knowledge acquisition.

\section{RESUMO}

A finalidade deste artigo é apresentar uma defesa do uso dos estudos de caso único em pesquisa de gestão. A defesa é necessária porque essa modalidade de pesquisa tem sido relegada a um papel secundário, ou até rejeitada, por muitos pesquisadores, por considerá-la não científica. Uma evidência desse baixo status é o fato de que os journals acadêmicos mais reputados na área de gestão publicam poucos artigos baseados em estudos de caso único. No presente artigo, examinamos em detalhe as objeções ao uso de casos na pesquisa de gestão, mostramos os esforços desenvolvidos por alguns pesquisadores para responder a essas objeções e mostramos critérios de qualidade de pesquisa alternativos àqueles utilizados no chamado "método científico". Nossa análise sugere que um melhor entendimento - por pesquisadores de diferentes preferências metodológicas - dos argumentos que justificam cada uso particular do estudo de caso único como método de pesquisa permitiria um melhor diálogo entre pesquisadores e beneficiaria a pesquisa de gestão em geral.

PALAVRAS-CHAVE | Pesquisa de gestão, estudo de caso único, metodologia de pesquisa, método científico, aquisição de conhecimento.

\section{FABIO LUIZ MARIOTTO}

fabio.mariotto@fgv.br

Ph.D. in Business Management at Stanford University, Stanford, California - United States of America

\section{PEDRO PINTO ZANNI}

pedro.zanni@fgv.br

Professor at Escola de Administração de Empresas, Fundação Getulio

Vargas, São Paulo, SP - Brazil

\section{GUSTAVO HERMIINIO SALATI} MARCONDES DE MORAES

gustavo.moraes@gvmail.br Professor at Fundação Escola de Comércio Álvares Penteado, São Paulo, SP - Brazil

\section{RESUMEN}

El artículo tiene por objeto presentar una defensa del uso de estudios de casos puntuales en la investigación en ciencias de la gestión. La defensa es necesaria porque este tipo de investigación ha sido relegado a un papel secundario o, incluso, rechazado por muchos investigadores que lo consideran poco científico. Una prueba de esta condición de inferioridad es el hecho de que la mayoría de las revistas académicas de renombre en ciencias de la gestión publican pocos artículos basados en estudios de casos puntuales. En este trabajo, examinamos en detalle las objeciones al uso de este tipo de caso en la investigación en ciencias de la gestión. Ponemos en evidencia los esfuerzos realizados por algunos investigadores para responder a las objeciones y exponemos criterios de calidad de la investigación que son una alternativa a los criterios usados en el llamado «método científico». Nuestro análisis sugiere que una mejor comprensión - por parte de los investigadores con preferencias metodológicas diferentes- de los argumentos relativos a cada uso particular de estudios de casos puntuales como método de investigación permitiría un mejor diálogo entre los investigadores y redundaría en beneficio de la investigación en ciencias de la gestión en su conjunto.

PALABRAS CLAVE I Investigación en ciencias de la gestión; estudios de casos puntuales, metodología de la investigación; método científico, adquisición de conocimiento. 


\section{INTRODUCTION}

Case studies constitute an important research tool in the field of management. In fact, case studies have been the source of some of the most trailblazing concepts in the field. Studies such as those by Chandler (1962), Penrose (1960), Peters and Waterman (1982), Pettigrew (1973), Prahalad and Hamel (1990), and many others, brought revolutionary insights to the field. Besides, the interest in case studies as a method for generating and testing theory has recently gained strength, especially in research in the areas of management (Cassel, Symon, Buehring, \& Johnson, 2006; Eisenhardt \& Graebner, 2007; Gibbert, Ruigrok \& Wicki, 2008; Lee, Collier, \& Cullen, 2007; Platt, 2007; Siggelkow, 2007). However, there still is a clear predominance of surveys and statistical methods - typical of positivist work and involving a large number of cases - in the studies published by the most prestigious journals (Gibbert, Ruigrok, \& Wicki, 2008; Lee, Collier, \& Cullen, 2007; Platt, 2007).

Yet, even if none calls in question the contribution of these landmark case studies, two facts tend to mar the acceptance of case studies in general among management researchers. One is that the most reputable journals of management publish few articles based on casework. The other fact is that this research method is often criticized in terms of its inherent inability to meet standard scientific criteria for research. Such criticism comes primarily from scholars with a positivist, normal science orientation. For some of these researchers, case studies may be used in research but are considered appropriate only in the preliminary stages of developing a new theory, when the relevant variables are still being explored (Cassel, Symon, Buehring, \& Johnson, 2006; Eisenhardt, 1989; Lee, Collier, \& Cullen, 2007; Platt, 2007). Such criticism may help explain the relative scarcity of published cases in reputable journals, but other reasons - such as the usually large and long effort needed to conduct a case study (Yin, 2009) - may also apply.

In this paper, we examine in detail the objections raised to the use of cases in management research, show the efforts spent by some researchers to respond to these, and show criteria of research quality - other than the ones usually used by positivist research - which are arguably more suitable to evaluate casework. The single case is focused here - as opposed to multiple cases - because the single case is the research design that most vividly brings out the contrast between case studies and the most prestigious research strategy used in management nowadays - sampling and statistical analysis via a large number of cases. We do not reject the latter approach and we acknowledge its importance, but we show that there are other valid ways for the acquisition of knowledge.
A case study might be regarded as a literary genre with many different applications. In fact, case studies are used in a variety of fields of learning, such as anthropology, psychology, education, medicine, law, business management, political science, and many others. The use each of these fields makes of case studies also varies, as will be seen below. Because of these different uses in different areas, definitions of what a case study is also vary considerably. A case study may be considered "a research method", "a methodological approach", "a research design", "a monographic approach", and so on. In most treatments of research involving cases, however, a single definition is given of a case study, which is the one the author of the text prefers and adopts for his/her work. In the words of Lincoln and Guba (1985: p. 360): "While the literature is replete with references to case studies and with examples of case study reports, there seems to be little agreement about what a case study is." For our purposes, we might define a case study as a detailed description of a management situation.

The following text is organized in three blocks. The first one presents the criticism of the single-case study as a research method. The two blocks that follow present responses to such criticism in the form of efforts to legitimize the single-case study as a research method. One block addresses efforts to meet positivist, normal-science criteria of what constitutes acceptable research practice; the other addresses efforts to meet different criteria.

\section{CRITICISM OF THE CASE STUDY AS A RESEARCH METHOD}

Despite the important historical role played by case studies in research in the field of management, many scholars have criticized the method. Critics of the case study as a research method tend to be academics embracing a positivist mindset. For them, the quality of a piece of research should be evaluated according to the positivist criteria of construct validity, internal validity, external validity, and reliability. Positivists have a realist ontological standing and seek to discover general laws that govern world phenomena. They adopt statistical methods, because they believe it is only possible to arrive at general laws by examining a large number of cases.

Criticism of case studies using positivist criteria argue as follows. As for internal validity - the extent to which we can infer that a causal relationship exists between two or more variables - and construct validity - the extent to which the constructs used in the case accurately measure the concepts they are intended to measure - criticism focuses on the impossibility of making controlled observations in a case study (in a lab- 
oratory or through statistical analysis). Critics also argue about the more basic impossibility of ensuring objectivity, in view of the possibility of cognitive distortion of data by the researcher conducting the study. Another aspect concerns the processes of deduction used by the researcher, because it is difficult to ensure that they are logical or controlled, being carried out by means of verbal propositions, not by mathematics; hence, the researcher can register false evidence or biased views (Lee, 1989; Yin, 2009).

According to the positivist outlook, the biggest limitation of a case study has been its virtual inability to provide a sound basis for the generalization of study findings. (This limitation is considered even more severe if the study involves a single case.) Often this is expressed as absence of external validity - the impossibility of extending the case study findings to a population of other cases (Donmoyer, 1990; Kennedy, 1979; Yin, 2009). Supporters of single case studies have developed a series of arguments - to be examined below - to solve the problem of "a sample of one" but none of the arguments has convinced those in favor of generalization by means of multiple cases or statistical samples.

Authors such as Donmoyer (1990), Kennedy (1979) and Yin (2009), believe increasing the number of data points in a single case would eliminate the problem. However, even with a larger number of data points, the single case remains unique (Ruddin, 2006).

As for reliability - the extent to which subsequent researchers can arrive at the same insights if they conducted the study following the same steps again - the critics point out that the case study cannot achieve it, since in the absence of controls the same conditions can hardly be repeated in other studies.

Defenders of the case study have responded to such criticism with a variety of arguments and proposals. These might be classified into two broad kinds: efforts to meet the current positivist criteria of normal science and efforts to promote different criteria, more suitable to case study research. Let us examine these arguments in detail.

\section{EFFORTS TO LEGITIMIZE THE SINGLE- CASE STUDY BY MEETING POSITIVIST CRITERIA FOR RESEARCH}

Some scholars of both the positivist and non-positivist camps have attempted to find ways of making case studies comply with normal-science criteria. Three proposals will be discussed here: the first is increasing the rigor in case studies, the second is us- ing the case to generate theory, and the third is using the case to falsify or refine an existing theory. These will be examined in turn.

\section{Increasing rigor in case studies}

From the time the case study started to become widely used by management researchers, one can observe a scattered effort to develop rigorous research procedures that would give this methodological approach scientific respectability, perhaps as convincing as the statistical methods widely used in the field. Supported by the positivist view of case studies such as that advocated by Eisenhardt (1989) and Yin (2009), different authors proposed research strategies that increase the accuracy of case studies with regard to their internal validity, construct validity, external validity and reliability (Gibbert, Ruigrok, \& Wicki, 2008).

Gibbert and Ruigrok (2010) nicely document this effort in their content analysis of the 159 cases published by 10 top management journals in the period 1995-2000. They found that few case study authors explicitly referred to the four aforementioned rigor criteria. Of those who did, some reported extensively concrete research actions taken to ensure rigor. Another finding, of great importance to the present discussion, was that papers addressing rigor reported strategies that were more detailed, thus ensuring internal and construct validity rather than external validity (i.e. generalizability).

Let us have a look at how the authors surveyed by Gibbert and Ruigrok (2010) dealt with the four criteria of case study rigor. They suggested following rules which are acceptable to reviewers and publishers. For the case study to have internal validity, the researcher must develop an argument that has a consistent causal construction (Siggelkow, 2007; Yin, 2009). To achieve this, one must formulate a clear research framework (with emphasis on relationships between variables and outcomes), analyze patterns and make the triangulation of data - using different sources of information for the same data (Eisenhardt \& Graebner, 2007; Gibbert, Ruigrok, \& Wicki, 2008; Yin, 2009).

To increase the construct validity of a case study it is important to establish a clear chain of evidence to allow the readers of the case to reconstruct how the researcher departed from the initial research questions and reached the final conclusions (Gibbert, Ruigrok, \& Wicki, 2008; Yin, 2005). For this purpose, "thick description" (Geertz, 1973) and triangulation (Stake, 2000; Yin, 2009) are indicated procedures (Gibbert, Ruigrok, \& Wicki, 2008). This carefulness in developing constructs, measures and testable theoretical propositions allows the inductive case study to be aligned with normal-science streams of research (Eisenhardt \& Graebner, 2007). 
The external validity or generalizability of the findings in a case study is a problematic criterion when applied to cases. It is well known that neither a study of a single case nor even of a few cases allow statistical generalizations - that is, extension of the study findings to a population of other cases. As will be shown below, there have been various attempts to deal with this shortcoming of case studies. According to the study done by Gibbert and Ruigrok (2010), some authors try to improve the external validity of their cases with multiple cases, using a nested approach, presenting a rationale for case selection, and providing details on case study context.

Reliability refers to the criterion that research must be such that if other researchers choose to follow the same research procedures, they can achieve the same insights as the initial researcher (Denzin \& Lincoln, 2000). For this to be possible, it is important for the researcher to ensure transparency of the research procedures in order to allow replication by other researchers (Eisenhardt \& Graebner, 2007). In this sense, well-described research procedures and protocols are essential parts (Gibbert, Ruigrok, \& Wicki, 2008). It is therefore important to stress the need for detail and depth in the fieldwork (Eisenhardt \& Graebner, 2007).

\section{Generating theory through a single case study}

The construction of theory with the help of case studies is a research strategy that involves the analysis of one or more cases to create theoretical constructs and/or propositions from the empirical evidence provided by the case (Eisenhardt, 1989; Eisenhardt \& Graebner, 2007; Platt, 2007; Yin, 2005). Therefore, the process of theory building through this methodological approach is inductive, i.e., the theory emerges as patterns of relationships between constructs are recognized in the case and between cases (Eisenhardt, 1989; Eisenhardt \& Graebner, 2007, Lee, Collier, \& Cullen, 2007; Siggelkow, 2007; Yin, 2009).

In management research, the interest in the case study as a method for generating and testing theory has recently gained strength, (Eisenhardt \& Graebner, 2007; Gibbert, Ruigrok, \& Wicki, 2008; Lee et al., 2007; Platt, 2007; Siggelkow, 2007). However, there is still a clear predominance of surveys and statistical methods as research tools in this area (Cassel, Symon, Buehring, \& Johnson, 2006; Gibbert, Ruigrok, \& Wicki, 2008; Lee et al., 2007; Platt, 2007).

Building theory from case studies is a research strategy proposed by Glaser and Strauss (1967), Eisenhardt (1989), and Yin (2009), among others. Eisenhardt and Graebner (2007) argue that it is one of the best (if not the best) bridges between rich qualitative evidence and mainstream deductive research. In addition, they contend that

since it is a theory-building approach that is deeply embedded in rich empirical data, building theory from cases is likely to produce theory that is accurate, interesting, and testable. Thus it is a natural complement to mainstream deductive research (Eisenhardt \& Graebner, 2007, pp. 25-26).

In addition, theory building from cases constitutes what Yin (2009) calls "analytic generalization", which he presents as a substitute for the "statistical generalization" of the hypothetical-deductive method. The latter is not possible with a single case or few cases. Instead of generalizing findings from a large sample of cases to a population of cases represented by the sample - as in the hypothetical-deductive method - the researcher generalizes findings in the single case or few cases to theory. For many users of case studies, this concept of generalization redeems the case study from the accusation of not being usable for generalization.

However, for the purpose of this article, which focuses on the single case, theory building is a more limited possibility, since most instances of theory building through cases feature multiple cases, not single ones. In addition, nearly all recommendations for doing high quality research in theory building from cases (e.g. Eisenhardt and Graebner, 2007; Yin, 2009) require the use of multiple cases.

Still, there is an acceptable role for a single case in theory building, when the case is unusually revelatory, or when it is extremely exemplar, or when it offers opportunities for unusual research access (Yin, 2009; Eisenhardt \& Graebner, 2007). In addition, even Eisenhardt and Graebner (2007), who generally advocate the superiority of multiple cases over single cases, recognize that

Somewhat surprisingly, single cases can enable the creation of more complicated theories than multiple cases, because single-case researchers can fit their theory exactly to the many details of a particular case. In contrast, multiple-case researchers retain only the relationships that are replicated across most or all of the cases (Eisenhardt \& Graebner, 2007, p. 30).

Tsoukas (2009) points out that the more researchers are concerned about understanding the specifics of a phenomenon, the more descriptive they will become and the more flex- 
ible they will be in terms of the theories they consider. On the other hand, the more researchers try to place their study within what is known about the phenomenon of interest, the more they will describe the phenomenon in terms of what has been defined in the literature. Thus, a single case study may bring an important contribution to theory development if the particulars of the case are seen as opportunities to make further adjustments in an already crystallized understanding of reality.

Therefore, without the specificity of particular cases, new distinctions are not possible. Thus, the main goal is not to seek the general laws that operate in the particular case, but to allow a better view, a better explanation (Tsoukas, 2009).

Despite these arguments justifying the use of case studies, to a positivist, single or multiple case studies would typically be acceptable only for providing inputs in the preliminary stages of developing a new theory, when the relevant variables are still being explored (Cassel, Symon, Buehring, \& Johnson, 2006; Eisenhardt, 1989; Numagami, 1998; Platt, 2007).

Anyway, if one's objective is to look for universal laws, the cases should be selected not because they are representative of a population, but because they are particularly suitable for the analysis of a specific theme, allowing connections between constructs that will lead to theoretical insights (Eisenhardt \& Graebner 2007, Siggelkow 2007). Thus, it is important to have in mind that while case studies can make use of quantitative data, the major emphasis is the study of phenomena within their contexts (Numagami, 1998; Platt, 2007; Pettigrew, 1973 as cited in Gibbert, Ruigrok, \& Wicki, 2008). In contrast to laboratory experiments in which the phenomena are isolated from their environment, case studies emphasize the context within which the phenomenon is embedded (Eisenhardt \& Graebner, 2007; Numagami, 1998; Platt, 2007; Yin, 1994).

Platt (2007) points out that clinical psychologists like Freud, for example, followed the medical tradition of using single-case studies to generate theory. For this, their overriding concern was to understand the specifics of a particular case under analysis, being less concerned with the potential for generalization of their findings. Still, the field of psychology developed under the strong influence of a statistical tradition, although many researchers consider it an inadequate scientific basis for psychological theory, since individual behavior can vary significantly from one context to another.

Lewis and Ritchie (2003) use the term "theoretical generalization" in referring to the generalization of theoretical concepts that seem to have a wider, even universal, application. In this case, the conclusions are the result of features and constructs developed in one or more case studies. These are then used to develop a broader theory. And Kennedy (1979) stressed that the value of single cases in generating non-statistical inferences should not be underestimated, especially in situations where new paths arise for which the inference rules have not been established.

\section{Falsifying or refining theory}

If normal-science, positivist criteria are followed, the only instance in which a case study may provide enough evidence for generalization is when the evidence found in the case negates an extant theoretical proposition (Popper, 1974). Falsification is probably the most rigorous test to which a theoretical proposition can be subjected. Indeed, the observation of a single instance in which the proposition does not hold true is generally sufficient for the proposition to be considered not valid, which requires that the proposition be either rejected or revised. Popper (1974), who originated this criterion, used the now celebrated example of the proposition "all swans are white," to make clear that just one observation of a single black swan would falsify this proposition. Such a result would stimulate further investigations and possibly revisions in the extant theory. The case study is well suited to identifying "black swans" because of its in-depth approach: what appears to be "white" often turns out on closer examination to be "black". Therefore, the case study is ideal for falsifying theories (Flyvbjerg, 2001, p.77).

\section{EFFORTS TO LEGITIMIZE THE SINGLE-CASE STUDY BY MEETING DIFFERENT CRITERIA}

Another basis for claiming legitimacy for case studies as research tools is to show, on one hand, that positivist, normal-science, criteria are not adequate for certain categories of research - in which case studies are mostly used - and, on the other hand, that case study research meets other quality criteria that are ignored by normal science.

These efforts have produced research assumptions and logics that are different from the logic and assumptions of normal-science, positivist research. While the latter regards the world as a real entity and seeks general laws governing world phenomena, most of the other assumptions and logics, to be described below, regard the world as a socially-constructed concept and seek to understand in depth the phenomenon described in each particular case.

We consider three of those efforts: rejecting the positivist criteria and enhancing the value of particularity, dismissing the importance of representativeness in certain types of research, and disciplining transfer of knowledge between cases. 


\section{Rejecting the positivist criteria and enhancing the value of uniqueness}

In the section where we discussed generating theory through a single-case study, we have already examined one strategy to counter the criticism that case studies cannot lead to statistical generalization, which is to resort to an alternative strategy, named "analytical generalization", in which the findings of a case study can be "generalized" to a theory (Yin, 2009). This way, the findings of a case study are seen as a preliminary step in the process of building a general theory, containing law-like propositions supposedly applicable to a population of similar cases. However, note that this is still one attempt to meet positivist criteria.

Another line of argument is to deny the need to find universal laws, applicable to a population of cases, under the assumption that the objective of social research is not to find universal laws but to gain a deep understanding of one particular case. This is typically the case in biography, institutional selfstudy, program evaluation, therapeutic practice, and other lines of work, in areas such as education, counseling, social work, therapeutic work, political science and others (Stake, 1994). We believe that management research may profit from assuming a similar posture.

There has been a long-standing debate on whether social phenomena should be researched using the same methods as in natural science. Flyvbjerg (2001, p. 26) comments that "the natural-science model has been, and continues to be, an ideal shared by several traditions in the study of human activity, such as positivism, functionalism, structuralism, cognitivism, and neopositivism." He asks "Can we speak of a unified science, or should natural-science inquiry and social-science inquiry be viewed as two basically different activities?" (Flyvbjerg, 2001, p. 25). By arguing that context and judgment are irreducibly central to understanding human action and by exploring whether a theory of context and judgment is possible and deciding that it is not, he concludes that social science's emulation of natural science is a blind alley. Different, specific criteria should be developed for social sciences, he says.

Specifically, some authors question the need - or even the feasibility - to pursue the four criteria of research rigor adopted in the natural sciences: construct validity, internal validity, external validity, and reliability. Numagami (1998) provides an example of this kind of reasoning. He objects to the normal-science requirement of reliability and generalizability of research findings in social sciences by questioning the possibility of establishing invariant laws for social phenomena. Numaga$\mathrm{mi}$ (1998) contends that reliability and generalizability (external validity) are relevant criteria only if the researcher is searching for an invariant and universal law. In fact, meeting these criteria would be impossible without an invariant law over time (Numagami, 1998). The applicability of these criteria to management studies depends, therefore, on one's accepting the existence of invariant laws in the field of management. Numagami (1998) cites authors who have recently attacked the premise of the existence of universal laws in social (especially management) phenomena, such as G. Sjoberg, N. Williams, T.R. Vaughan, and A.F. Sjoberg (1991), Tsoukas (1989), and Whittington (1988). Numagami (1998) sets himself to clarify the conditions under which invariant laws may be found in management and observes that these conditions are so stringent that they would not be satisfied in most real-world instances. In addition, he argues that the quest for external validity and reliability may work against the very biggest benefits that case studies can bring, namely those related to specific and contextual issues that case studies are better at detecting. He concludes by suggesting that serious consideration be given to whether the objective of management studies should be changed from a search for invariant laws of practical use to the encouragement of reflective dialogue in society (Numagami, 1998).

Other authors argue that generalization should not necessarily be a goal in every research work (Platt 2007; Stake, 2000), especially in those that use qualitative research methods. Stake (2000) draws attention to those instances in which the will of the researcher to hit upon generalizable findings is so strong that it distracts him/her from issues that are fundamental for understanding the case itself. Still arguing against the common quest for generalization, Stake contends, "the objective of the case study is not to represent the world, but to represent the case" (Stake, 2000, p. 245).

Furthermore, in reflecting on the use of single cases, Stake (2000) asserts that - counter-intuitive as it may seem the generalizations that derive from the comparison between two cases are less reliable than those arising from in-depth analysis of a single case. This is because the single case allows a more precise understanding of the circumstances in which the phenomena occurred and therefore tend to be more reliable.

\section{Dismissing representativeness as a criterion}

The normal science concern for generalization often surfaces in the allegation that a single case study must be representative of a population of cases. Yet, there are many situations where it is the study of a particular aspect that brings to light the most valuable insights about a given situation. In contrast, in most situations where the researcher seeks a general feature shared 
among many cases - as when seeking an invariant law - no interesting insights are produced (Cassel, Symon, Buehring, \& Johnson, 2006; Lee, Collier, \& Cullen, 2007; Siggelkow, 2007).

If these arguments are accepted, the case needs not be representative of a given population nor must it be chosen at random. Rather, it is often desirable to choose a particular object or situation precisely because their unusual characteristics allow for the generation of insights that other cases could not generate (Numagami, 1998; Siggelkow, 2007). Siggelkow (2007) provides a curious parable to highlight both the value of a single case and the difficulty that some researchers often face to recognize its value:

You cart a pig into my living room and tell me that it can talk. I say, "Oh really? Show me.” You snap with your fingers and the pig starts talking. I say "Wow, you should write a paper about this." You write up your case report and send it to a journal. What will the reviewers say? Will the reviewers respond with "Interesting, but that's just one pig. Show me a few more and then I might believe you"? (Ramachandran, 1998 as cited in Siggelkow, 2007, p. 20)

Through this parable, Siggelkow (2007) wants to stress that a single case can be a very powerful example, yet it runs the risk of being scorned at for not being representative. Note in the parable that I, the unbeliever, pushed by the habit of generalization, am seeking to generalize the phenomenon I just observed to an invariant law such as "all pigs talk", while you are interested in the singular, rare phenomenon itself, perhaps to study it better and find an explanation of how that pig is able to talk.

A real-life example of the value of a case not being representative of a given population is provided by Starbuck's (1993) account of a New York law firm that was enjoying exceptional success, arguably because it adopted policies and guidelines that differed markedly from those of the other law firms in the city.

\section{Disciplining the transfer of knowledge between cases}

A single case study may also lend itself to generalization to other cases, if by "generalization" we mean the application of a study's findings to just another single case - and not to a whole class of cases. In this section, we will examine a few proposals of how to conceive of this type of "generalization".

This transfer of findings from one case to another case is common in the realm of practice. In the legal field, for example, the study of a single-case, in countries that adopt the common law legal system, is a good example of generalizing from a specific case. In these situations, the decision of whether the characteristics of the previous case can be applied to the case being tried is up to the judge. He is the one who reads the case and decides whether it can be applied to his/her case (be "generalized") or not. According to the legal tradition, the judge's decision is guided primarily by four attributes: i) whether the material facts of the two cases are similar, ii) whether the decision taken in the previous case would still be fair considering possible changes in context, iii) reasons for a particular decision and iv) the level of generalization upon which the decision was made (Kennedy, 1979). Kennedy also points out that, while many researchers are not accustomed to the idea of leaving generalization to the reader of the case study, this is common practice, particularly in the legal and clinical fields.

In the field of clinical treatment, both medical and psychological, a lot of accumulated knowledge comes from findings in previous individual cases. As in legal cases, clinical generalizations (i.e., transfer of findings to another case) are the responsibility of the receiver of information. So, the one who describes the original case should be very careful to provide a sufficient amount of information to allow such generalization. Accordingly, three criteria are important for those who generate the information: i) presentation of longitudinal information, ii) a multidisciplinary assessment of patients and iii) accurate description (Kennedy, 1979). Analogous procedures might be adopted in management research.

In research work, some authors who accept the transfer of findings between cases assert that research based on single-case studies need not necessarily present the possibilities of generalization of their findings explicitly, even if the authors are aware of possible generalizations. The most important thing in these situations is the use that other researchers make of the case, doing what is called "naturalistic generalization" by Stake (1982) or "heuristic generalization” by Tsoukas (2009), “inferential generalization" by Ritchie and Lewis (2003) and "transferability" by Hellstrom (2008) and Lincoln and Guba (1985). These authors claim that the task of generalizing is the reader's (Gomm, Hammersley \& Foster, 2000; Stake 1983). Transferability should be understood not as the reproduction of the results of one case maintained under the same conditions in previous studies to reproduce the results (as in statistical generalization), but the possibility of applying results obtained in the case study to similar situations, respecting the peculiarities of the new contexts.

In the same line of argument, Tripp (1985) stresses that it is up to the recipient of the information to determine whether the findings of a case can be applied in a new situation. The rules 
by which judgments are reached concerning generalizability (i.e., transferability) may be useful for those who need to judge the generalization of a single case study to their own situation. In other words, this sort of generalization is based on the experience of the reader, not only on rational laws (Lewis \& Ritchie, 2003).

Tsoukas (2009) points out that in this process, in which the reader examines the case and makes decisions about the possibilities of generalization to their specific context; there is a tacit recognition of similarity, based on personal involvement. In this process, the reader recognizes the phenomenon when he sees it, but cannot define it exhaustively. Thus, what defines the logic of the phenomenon is not a dominant feature, but similarities that overlap, analogous to the similarity between members of one family. It is therefore a kind of tacit recognition of similarity, based on personal involvement. Therefore, only the researcher who reads the case study thoroughly can transfer the findings to a new situation (based on his/her tacit knowledge and experience of life) (Hellstrom, 2008).

We will briefly examine three specific proposals of how to conceive such a transfer. Even if their authors suggest ways of transferring findings from one case to another, all have explicitly declared that they were more interested in deeply understanding one particular case than in generalizing the findings of the case in the form of general laws.

As mentioned above, a conception of such transference is that proposed by Stake $(1978,1982)$, who called it "naturalistic generalization". This term deserves some clarification. "Naturalistic" is used here to mean that the phenomenon is observed in its natural context and that the researcher introduces no outside stimulus, instead witnessing behavior as it naturally occurs in the environment. "Generalization" as used here means knowledge (mostly tacit, see Polanyi, 1958) which is usually acquired by direct experience, but may also be acquired through vicarious experience - undergone by the reader of the case in place of its author or actors (Stake, 1978, 1982).

It seems to us ... that the kind of knowings generated by experiencing, whether direct or vicarious, are different from the knowings which are the result of [positivist] research activity. Research typically aims to produce explicit, articulated, formal knowledge. The knowings which arise from experience are more tacit, implicit, personalistic. These are self-generated knowings, naturalistic generalizations, that come when, individually, for each reader, each practicioner, new experience is added to the old (Stake, 1982, p. 3, italics in original).
A second conception of using a single-case study to transfer knowledge acquired in the study to other cases is that of Lincoln and Guba (1985), who propose the term "transferability" for the possibility of having research findings from a given context apply to another context. Findings from one case should be regarded as working hypotheses and transferability depends on the degree of congruence between sending and receiving contexts, which they call "fittingness". Lincoln and Guba's (1985) approach has many similarities with Stake's $(1978,1982)$ naturalistic generalization. However, they prefer not to use the term "generalization" - with its positivist connotations - and declare that "the only generalization is: there is no generalization" (Lincoln \& Guba, 1985, p. 110). They also remark:

An investigator can make no statements about transferability for his or her findings based solely on data from the studied context alone. At best the investigator can supply only that information about the studied site that may make possible a judgment of transferability to some other site; the final judgment on that matter is, however, vested in the person seeking to make the transfer, who must be in possession of similar data for the receiving context (Lincoln \& Guba, 1985, p. 217).

Lincoln and Guba (1985), in reflecting on the naturalistic generalization proposed by Stake (1982), and considering that generalization occurs only from the standpoint of the reader, i.e., based on tacit knowledge, have questioned whether generalization can be communicated to others through a common language. They conclude that, unlike logical generalization (supported by concepts such as sample and population), naturalistic generalization seeks a psychological generalization, involving concepts such as cognition, abstraction and understanding (Lincoln \& Guba, 1985).

In this view that the researcher's role is to provide elements for the reader to draw his/her own conclusions, Lincoln and Guba (1985, 2000) suggest that the researcher's responsibility is to provide sufficient contextual information to facilitate the reader's judgment as to whether the features and findings of a case can be transferred from one situation to another. Stake (1982) also emphasizes that the main role of researchers of the single-case study is not to provide generalizations, but to illustrate the case adequately, capturing its unique characteristics. Donmoyer (1990) emphasizes the importance of the narrative being well developed (with much information) and the researcher not seeking to present interpretations, but only to increase 
the possibility of interpretations available to the reader. This is because a "thick description" (i.e., a very detailed and comprehensive account) increases the case's accessibility, allowing the reader to experience a situation in which he was not in fact present. In addition, the researcher creates the possibility that the reader sees through the researcher's eyes. Thus, the researcher must provide detailed knowledge of the situation in order to allow the reader to establish the similarities that will allow the adequacy of his/her judgment (Hellstrom, 2008; Kennedy, 1979; Lincoln \& Guba, 1985).

Donmoyer (1990) proposes a third conception of transferring findings. He shares with Stake $(1978,1982)$ and Lincoln and Guba (1985) the interest in the single study. He uses the terms "generalization" and "generalizability" in the sense of transferring single-case findings to another case, as Stake and Lincoln and Guba do. However, he claims to advance the application of these ideas. He starts by noting that Stake $(1978,1982)$ does not explain how in-depth knowledge of a single case helps us understand and act more intelligently in other potentially different cases. As for Lincoln and Guba (1985), Donmoyer argues that their assumption that findings are only transferable from the studied case to another if the contexts are similar may not be true.

Donmoyer (1990) proposes an alternative conceptualization, based on his experience in the field of education. He criticizes the positivist concept of knowledge accumulation mainly for its neglect of experiential knowledge. The positivist concept is less than adequate, he says, because it ignores tacit knowledge; thus, propositional language of hypotheses is too crude a tool to encompass all that we learn from experience. In addition, he contends that, in education, the relationship of teachers and students, or in health care, of clinicians and patients is not similar to the relationship of scientist and subject. (We believe that an analogous reasoning applies to the relationship between a researcher or a consultant and a manager in the field of management.) $\mathrm{He}$ also notes that knowledge gained in experiential knowledge is not purely intellectual, but it is often affect-laden. This implies that much of the learning consists of meaning-making.

One is reminded of the essay by March, Sproull and Tamuz (1991) arguing that cases may be used as mechanisms for interpretation and generation of meaning in organizations. They reflect on processes of organizational learning and show the role of single cases (or fragments of a particular history) in the construction of shared interpretations, valid knowledge, and increased organizational performance (March, Sproull, \& Tamuz, 1991). These authors also contend that single cases offer organizations valuable mechanisms that help one organize and interpret experience in order to build a shared understanding of it. Furthermore, the existence of these shared beliefs has great advantages, even if the resulting interpretation is not entirely correct. Among these advantages is the possibility to increase the potential of learning arising from a single or even ambiguous event and imaginatively build hypothetical stories, but with deep meaning for the organization.

Donmoyer (1990) proposes the use of schema theory language, developed by Piaget, according to which "generalizability" of experiential learning (transfer of knowledge from one situation to another) involves processes of assimilation, accommodation, integration, and differentiation. Donmoyer remarks that single-case studies work as vicarious experience; therefore, they must undergo similar processes if schema theory is accepted. Vicarious experience has at least three advantages over direct experience. First, it is more accessible, since it takes the reader to different places and to different individuals. From the perspective of schema theory, the purpose of research is simply to expand the range of interpretations available to research consumers (readers). A second advantage of vicarious versus direct experience is that the reader is able to see through the researcher's eyes, therefore seeing things that he/she otherwise might not have seen. Put another way, the case study - in this perspective - can enlarge the reader's cognitive structure. Consequently, his/her own cognitive repertoire will be expanded (Donmoyer, 1990). The third advantage is that vicarious experience is less likely to produce defensiveness and resistance to learning (before the experience) than direct experience. This is because, when people live through the experience of others, personal barriers to assimilation of the phenomenon end up being smaller, and this facilitates the learning process (Donmoyer, 1990).

Note that this mindset introduces a form of knowledge building that is radically different from the classical, normal-science way. Instead of disseminating explicit theories and generalizations, Stake (1978, 1982), Lincoln and Guba (1985), and Donmoyer (1990) advocate the building of individual knowledge, which is, to a great extent, personal knowledge as defined by Polanyi (1965).

\section{A NOTE ON THE USE OF SINGLE-CASE STUDIES IN MANAGEMENT RESEARCH IN BRAZIL}

In the text above, we cite only studies published in English, which tends to reflect the mindset of Anglo-Saxon academia. We are sure there are many critical writings about the single-case 
study published in other countries and in other languages. Examination of potential contributions that such studies could give the discussion of the subject treated here is unfeasible because of the sheer size of the task, not to mention the language barrier. However, as the authors of this article are Brazilian, it is worth including here a rapid survey of the use of single-case studies in Brazilian research on management. Unfortunately, we have not found published Brazilian research focused specifically on single-case studies in management research and written in English. Therefore, the papers we will refer to in this section were published in Portuguese.

Researchers in management in Brazil have proven to be intensive users of the single-case study. This usage entered a phase of great expansion starting in the 1980's. The publication of the first edition (in English) of Yin's (1984) book, followed by successive editions and its translation into Portuguese (Yin, 2001) had a visible impact on this expansion. The book by Martins (2006), as well as articles by Lazzarini (1995), Bressan (2000), Alves-Mazzotti (2006), Godoy (2006) and Martins (2008), among others, are texts with an educational purpose, directed to beginning researchers in applied social sciences, especially in management. In general, these texts implicitly seek to reconcile the conflict between nomothetic approaches (search for general laws) and idiographic approaches (search for a deep understanding of a single case). They typically follow Yin's proposal: to increase the rigor of the single case study through the adoption of a variety of technical and formalized procedures in order to legitimize the case's findings.

Some journals published in Brazil as well as some scientific meetings held in this country have contributed to the method's diffusion. An example is the Revista de Administração Contemporânea (Journal of Contemporary Management), published since 1997, which often brings research using single-case studies (it also includes teaching cases - "cases" written for class discussion - in a separate section). Another example is found in papers presented at the annual meetings of the Brazilian Academy of Management (ENANPAD), where the presence of single-case studies in research is constant. Within the EPQ Academic Division of the same meetings -- EPQ stands for Teaching and Research in Management and Accounting - the use of single-case studies in research has been examined and discussed.

Despite this intense use of the method, reflexive and critical writings on the use of single-case study are rare in Brazilian literature and nonexistent - or at least unknown to us - in English. Among the critical texts in Portuguese, the work of Pedro Lincoln Mattos is worth mentioning. He is possibly the Brazilian author whose production is most akin to the themes of the present article. Two articles are especially relevant to the assessment of the single-case study as a research method. In the first article, Mattos (2005) proposes a strategy for the single-case study as a learning object, inspired by the Delphi Method. He draws attention to the affinity between the methodology proposed in the article and the use of the "case method" widely used in business schools, in which "cases" are written specially for class discussion. Mattos (2005, p. 2) remarks: "At bottom, the distinction between learning strategy and research strategy begins to disappear - and there are other good reasons to welcome the fact". It is here that a great similarity reveals itself between this perception and the discussion presented in the section of the present article about disciplining the transfer of knowledge between cases, where we point to the role the case study may have as a vehicle for transferring individual knowledge. In the second article, Mattos (2011) explains and criticizes the various conceptions of generalization of the results of a qualitative piece of research. The article covers several of the ideas presented here, but the treatment (post-positivist) that Mattos gives the theme is far more erudite (quoting from Hume to Habermas) than ours. On the other hand, it is possibly less accessible to novices in management research.

\section{CONCLUSION}

The study of a single real case has been widely used as a source of knowledge in several areas, whether as an example to be followed, a sample of what can happen, or a source of vicarious experience. Investigators wishing to contribute to the acquisition and dissemination of scientific knowledge have also frequently used narratives of cases. This has also been happening in management research. Nobody denies that case studies are useful for the acquisition of knowledge. However, disagreement exists among scholars of many fields of study, including management research, about what role case studies legitimately play in scientific research. Criticism of single-case studies focuses on the lack of scientific rigor and reliability in the method and especially on its inability to provide a basis for generalization of findings. This criticism originates in a normal-science, positivist approach to the acquisition of knowledge. Based on the issues raised in the present paper, one may distinguish two different ways of generating and diffusing knowledge. In one, known as "scientific method", adopted in positivist research work, hypotheses about a certain type of phenomenon are suggested by theory or experience; these hypotheses are tested and, if accepted, are converted into general laws, applicable to a certain kind of phenomena. This method is nomothetic, that is, dedicated to the study or discovery of general scientific laws. In the oth- 
er way to generate and diffuse knowledge, a single instance of a certain phenomenon is thoroughly studied in its smallest details by an observer who then organizes his/her observations, notes salient ones - the study findings - and writes a report. The knowledge acquired by the observer/author in this way is not limited to what is reported in the case study, but also includes tacit knowledge gained by the case author by being exposed to the experience of observing the phenomenon. Up to this point, therefore, the knowledge generated by the case study is greatly confined to the researcher. The subsequent diffusion of knowledge is an important characteristic of this mode of knowledge acquisition. It occurs when somebody (an academic or a practitioner) attempts to apply the case study findings to a new situation. To do this, he/she must subject him/ herself to the experience undergone by the case writer in a vicarious way, through the reading and analysis of the case report. That is why the writer must provide a "thick description" of the case. The reader must thus judge the adequacy of transferring each finding from the original case to a new case. This way, the process of knowledge diffusion occurs case to case. This approach is idiographic, that is, concerned with discrete or unique facts or events (e.g. history is an idiographic discipline, studying events that cannot be exactly repeated).

The epistemological standings underlying the two radically different approaches to knowledge acquisition can be captured by the two questions: "What is going on here?" and "What is this a case of?" (Tsoukas, 2009). A researcher can assume these contrasting postures. In the first one, he/she seeks the peculiarities of the case, the things that make it different from other cases. In the second one, he/she seeks the characteristics that make the case belong to a pre-defined class of cases.

Different epistemological postures suggest adhesion to different research paradigms, therefore irreconcilable philosophical positions. We prefer to adopt a different view of the dispute. If we look at the literature we reviewed in this essay, we see that another feature of a (social) phenomenon seems to dictate what method will be used to study it: the use to be made of the study. The normal science, positivist, nomothetic approach tends to be used when a general guidance is needed, such as "profitability increases with market share". This will be useful in drawing the manager's attention to a relationship that is very relevant but it will not explain the cause of this relationship. The post-modern, constructivist, idiographic approach tends to be used when the manager wants to understand a rare event, such as an organizational crisis or oddity, an example being a large market share with low profitability.

If these points are accepted, it will become clear the two approaches are not incompatible, and they may be complemen- tary. Based on our review, we suggest that a better understanding by researchers holding different philosophical persuasions of the arguments that justify each particular use of the case study as a research method would allow a better, reflexive dialogue among researchers and benefit management research as a whole.

\section{REFERENCES}

Alves-Mazzotti, A. J. (2006). Usos e abusos dos estudos de caso. Cadernos de Pesquisa, 36(129), 637-651.

Bressan, F. (2000). O método do estudo de caso. Administração On Line, 1(1), 1-13.

Cassel, C., Symon, G., Buehring, A., \& Johnson. (2006). The role and status of qualitative methods in management research: an empirical account. Management Decision, 44(2), 290-303.

Chandler, A. D. (1962). Strategy and structure. Cambridge, MA: Harvard University Press.

Denzin, N. K., \& Lincoln, Y. S. (2000). Handbook of qualitative research. London: Sage.

Donmoyer, R. (1990). Generalizability and the single-case study. In Eisner, E. W. \& Peshkin, A. Qualitative inquiry in education: the continuing debate. New York: Teachers College Press.

Eisenhardt, K. M. (1989). Building theories from case study research. Academy of Management Review, 14(4), 532-550.

Eisenhardt, K. M., \& Graebner, M. E. (2007). Theory building from cases: opportunities and challenges. Academy of Management Journal, 50(1), 25-32.

Flyvbjerg, B. (2001). Making social science matter. Cambridge: Cambridge University Press.

Geertz, C. (1973). The Interpretation of culture. New York: Basic Books.

Gibbert, M., Ruigrok, W., \& Wicki, B. (2008). What passes as a rigorous case study? Strategic GManagement Journal, 29(3), 1465-1474.

Gibbert, M. \& Ruigrok, W. (2010). The "what" and "how" of case study rigor: three strategies based on published work. Organization Research Methods, 13(4), 710-737.

Glaser, B. \& Strauss, A. (1967). The discovery of grounded theory: strategies for qualitative research. New York: Aldine de Gruyter.

Godoy, A. S. (2006). Estudo de caso qualitativo. In: Godoi, C. K., Bandeira-de-Mello, R. and Silva, A. B. (orgs.), Pesquisa qualitativa em estudos organizacionais: paradigmas, estratégias e métodos. São Paulo: Saraiva, 115-146.

Gomm, R., Hammersley, M., \& Foster, P. (2000). Case study and generalization. In: R. Gomm, M. Hammersley, \& P. Foster (Eds.), Case study method: key issues, key texts. London: Sage, 98-115.

Hellstrom, T. (2008). Transferability and naturalistic generalization: new generalizability concepts for social science or old wine in new bottles? Quality and Quantity, 42(3), 321-337.

Kennedy, M. (1979). Generalizing from single case studies. Evaluation Review, 3(4), 661-679.

Lazzarini, S. G. (1995). Estudos de caso: aplicabilidade e limitações do método para fins de pesquisa. Economia \& Empresa 2(4), 17-26 
Lee, B., Collier, P., \& Cullen, J. (2007). Reflections on the use of case studies in the accounting, management and organizational disciplines. Qualitative Research in Organizations and Management: an International Journal, 2(3), 169-178.

Lee, A. S. (1989). A scientific methodology for MIS case studies. MIS Quarterly, 13(1), 33-50.

Lewis, J., \& Ritchie, J. (2003). Generalizing from qualitative research. In: Qualitative Research Practice. London: Sage.

Lincoln, Y., \& Guba, E. (1985). Naturalistic inquiry. Newbury Park, CA: Sage.

March, J. G., \& Sproull, L. S., \& Tamuz, M. (1991) Learning from samples of one or fewer. Organization Science, 2(1), 465-471.

Martins, G. A. (2006). Estudo de caso: uma estratégia de pesquisa. São Paulo: Atlas.

Martins, G. A. (2008). Estudo de caso: uma reflexão sobre a aplicabilidade em pesquisas no Brasil. Revista de Contabilidade e Organizações, 2(2), 8-18.

Mattos, P. L. (2005). Narrativa grupal mediada: uma estratégia para o estudo de caso como objeto de aprendizagem. In: XXIX ENANPAD, CDROM, 1-14.

Mattos, P. L. (2011). "Os resultados desta pesquisa (qualitativa) não podem ser generalizados": pondo os pingos nos is de tal ressalva. Cadernos EBAPE.BR, 9(special edition), 450-468.

Numagami, T. (1998). The infeasibility of invariant laws in management studies: a reflective dialogue in defense of case studies. Organization Science (9)1, 1-15.

Penrose, E.T. (1960). The growth of the firm - a case study: the Hercules powder company. Business History Review, 34(1), 1-23.

Peters, T.J. \& Waterman, R.H. (1982). In search of excellence: lessons from America's best-run companies. New York: Harper \& Row.

Pettigrew, A. (1973). The politics of organizational decision making. London: Tavistock.

Platt, J. (2007). Case study. In: Outhwaite, W. \& Turner, S. The sage handbook of social science methodology. London: Sage.

Polanyi, M. (1958). Personal knowledge. New York: Harper \& Row.

Popper, K. (1959). The logic of scientific discovery. London: Hutchinson.

Prahalad, C.K. \& Hamel, G. (1990). The core competence of the corporation. Harvard Business Review, 68(3), 79-91.
Ruddin, L. P. (2006). Can you generalize stupid! Social scientists, Bent Flyvbjerg, and case study methodology. Qualitative Inquiry, 12(4), 797812.

Siggelkow, N. (2007). Persuasion with case studies. Academy of Management Journal, 50(1), 20-24.

Sjoberg, G., Williams, N., Vaugham, T.R., \& Sjoberg, A.F. (1991). The case study approach in social research: basic methodological issues. In: Feagin, J.R., Orum, A.M., and Sjoberg, G. (Eds.) A case for the case study. Chapel Hill, NC: University of North Carolina Press, 27-79.

Stake, R.E. (1978). The case study method in social inquiry. Educational Researcher, 7(2), 5-8.

Stake, R. (1982). Naturalistic generalization. Review Journal of Philosophy and Social Science, 7(1-2), 1-12.

Stake, R. (2000). The case study method in social inquiry. In Norman K. Denzin \& Yvonne S. Lincoln. The American tradition in qualitative research. Vol II. Thousand Oaks, California: Sage Publications.

Stake, R.E. (2005). Qualitative studies. In: Denzin, N. K., \& Lincoln, Y. S. The Sage Handbook of Qualitative Research, pp. 443-466.

Starbuck, W. H. (1993). Keeping a butterfly and an elephant in a house of cards: the elements of exceptional success. Journal of Management Studies, 30(6), 885-921.

Tsoukas, H. (1989). The validity of idiographic research explanations. Academy of Management Review, 14(4), 551-561.

Tsoukas, H. (2009). Craving for generality and Small-N Studies: The Wittgesteinian Approach Towards the epistemology of the particular in organization and management studies. In: Buchanan, D. A. Bryman, A. Organizational Research Methods. London: Sage.

Tripp, D. (1985). Case study generalization: an agenda for action. British Educational Research Journal, 11(1), 33-43.

Whittington, R. (1988). Environmental structure and theories of strategic choice. Journal of Management Studies, 25(6), 521-536.

Yin, R. K. (1984) Case study research: design and methods. Beverly Hills, CA: Sage Publications.

Yin, R. K. (2001). Estudo de caso: planejamento e métodos, 2ª ${ }^{-}$ed. Porto Alegre: Bookman

Yin, R. K. (2009). Case studies: design and methods, 4th ed.. Thousand Oaks: Sage Publications. 